\title{
Country Branding: The Personality of Vietnam as a Brand
}

\author{
Kawpong Polyorat \\ Faculty of Business Administration and Accountancy, Khon Kaen University
}

Sathira Tassanawat

Faculty of Business Administration, Sripatum University-Khon Kaen

\begin{abstract}
Country as a brand reflects the marketing orientation to manage a country image to achieve the desired country position. Country personality is an important marketing strategy for this purpose. The present study attempts to examine the country personality of Vietnam, a major emerging Asian country. This exploratory study adopts Aaker's (1997) brand personality framework to uncover the country personality of Vietnam. Data were collected with Thai undergraduate students. Results from a factor analysis reveal 9 dimensions of Vietnam's country personality including competence, excitement, ruggedness, sophistication, new generation, down-to-earth, elegance, originality, and spiritedness. A number of theoretical and practical implications regarding country branding and country personality can be drawn from the study results.
\end{abstract}

Keywords: brand, country branding, country personality, Vietnam

\section{Introduction}

From a marketing perspective, country branding reflects the idea that a country can be viewed as a brand. As a result, different countries may possess different qualities or characteristics as do different branded products (Anholt 2003). For instance, assertiveness and ruggedness may reflect the characteristics of the US, whereas the humble traits could be associated with Japan (Sirisoontorn \& Polyorat 2013).

While country branding has attracted considerable attentions from both marketing managers and reserchers in Europe, North American and Australia (Pitt et al 2007), there has been relatively few studies conducted in the Asian context although this region plays an increasingly important role in the emerging economy. The current study thus aims to contribute to the knowledge in this topic by exmaming Vietnam, an important Southeast Asian country.

At present, Vietnam is one of the fascinating destinations, from not only tourists but also investors, probably for three crucial factors. First, the tourism industry in Vietnam has been rapidly growing. There are 972,800 international tourists in Vietnam in May 2017, representing a surge of 26.8 percent from the same month a year earlier (Trading Economics 2017). Second, Vietnam is an attractive country for foreign investors. Vietnam has attracted more foreign direct investments (FDI). In 2016, FDI inflows have steadily and significantly increased to 24.4 billion US dollars or 9 percent growth compared with that of 2015 (Dezan Shira \& Associates 2017). Finally, there has also been a considerable growth in Vietnam's export. In 2016, Vietnam's export reached 176.6 billion US Dollars (talkvietnam 2017). Its main export products include telephone and spare parts, textile, and computers. Based on these several important reasons, Vietnam therefore warrants more studies regarding its country branding.

One important concept in brand building is brand personality. Human personality traits such as sincere, friendly, or charming can be used to describe a brand and are thus called brand personality. Brand personality may send a message that a given brand is special by communicating different personality traits to make customers perceive and interpret the special brand characteristics )Plummer, 2000(. Brand personality that provides abstract meaning which corresponds with the identity of customers are likely to be viewed as more favorable )Kim et al., 2005(. While there are several studies on brand personality for traditional branded products, relatively few studies have attempted to apply the brand personality concept to countries (Amatyakul and Polyorat 2016). This is surprising given that several countries have actively tried to 
promote their countries for tourism, export, investment, or other business purposes. Therefore, the present study attempts to demonstrate that a country has personality as do traditioinal branded products. It is expected that the results from this study may provide insightful guidelines in the development of country marketing campaign and also suggest avenues for more systematic applications of the brand personality concept to non-traditioinal branded entities.

\section{Theoretical Framework}

\section{Country Branding}

A country may change or manage its image in order to systematically enhance, modify, or improve its reputation (Fan, 2009), resulting in a more favorable or better evaluation of that country. This practice of the so-called country branding is therefore a national strategy to survive or stand out in the present days where competitions among countries become more heightened (Kaneva, 2011).

Research in country branding may cover such different areas as public diplomacy, country-of-origin, destination or place branding, and identity of the nation (Fan, 2009). From the marketing viewpoint, whereas destination branding and countryof-origin concentrate on enhancing economic competitive advantages of a given country especially in terms of tourism and import-export, country branding focuses, however, on the country's overall image and positioning in the international eyes. Therefore, country branding also covers cultural, political, and technological dimensions of a country (Kaneva, 2011).

Country branding requires more complex marketing strategies than those of traditional branded products because a country may possess relatively more uncontrollable, interconnected, intangible, and emotional characteristics (Mugobo and Ukpere, 2011). Six primary elements including culture, people, tourism, exports, governance policy, investment, and recruitment (Anholt, 2003) may be pertinent and thus used by a country to communicate its country characters to the audience. In addition, consumer perceptions of a given country may also be based on such various factors as use of product originated from the country, personal familiarity with the country, understanding about the country, stereotypes of the country, and media coverage of the country. As a result, country branding must match the country's image with the reality of these relevant factors and communicate them to the audiences in order to gain more favorable reputation (Fan, 2009).

\section{Brand Personality}

Brand personality is defined as a set of human characteristics that relates to brands (Aaker 1997( and provides symbolic meaning of brands (Sung and Tinkham (2005). For example, Absolut Vodla is a 25 -year old person with a cool and modern personality (Balakrishnan et al 2009). Because brand personality is relatively more difficult to imitate than tangible product attributes, brand personality can thus be used to achieve a more sustainable advantage (Ang and Lim 2006).

Past brand personality research has covered the relationships between brand personality and several other marketing variables including brand loyalty )Farhat and Khan, 2011, Lin, 2010(, human and consumer personality (Lee, 2009, Balaji and Raghavan, 2011, Ekhlassi et al., 2012), consumer attachment to brand )Goldsmith and Goldsmith, 2012(, image of product user (Parker, 2009), and acknowledgement of product quality )Ramaseshan and Tsao, 2007.

Based on a series of surveys, Aaker (1997) uncovers five dimensions of brand personality: sincerity (down-to-earth, honest, wholesome and cheerful), excitement (daring, spirited, imaginative and up-to-date), competence (reliable, intelligent and successful), sophistication (upper class and charming) and finally ruggedness (outdoorsy and tough). The robustness of these five dimensions are reported across different genders, age groups, brands, and product categories. Despite some criticisms, several of the brand personality studies conducted after 1997 are based, at least in part, on Aaker's (1997) framework (Azoulay and Kapferer 2003).

\section{Method}

Country personality of Vietnam was measured with Aaker's (1997) 42-item brand personality scale. The original scale in English was translated to Thai using a back-translation procedure (Brislin 1980). The research participants were instructed to think of Vietnam as if it were a person and to rate on a five-point ( $1=$ not at all descriptive, $5=$ extremely descriptive) the extent to which each of the 42 brand personality traits described the country.

Three hundred and sixty-eight students from a major northeastern Thai university participated in this study via judgmental sampling. They filled out the survey during regular class hours as part of the course requirement. The age of the 
participants varied from 18 to 37 years with the mean value of 20 years. Female participants accounted for $62.5 \%$ of the sample. Subjects were first informed of the study description, then asked to complete the Aaker's (1997) brand personality scale and provide demographic data including age and gender.

\section{Results}

The 42 items from Aaker's (1997) brand personality scale were submitted to principal component factor analysis with a varimax rotation. Items which had low factor loadings (<.50) were removed. As a result, 36 items remained for further analysis. The means, standard deviations, fator loadings, eigenvalues, and percentage of variance explained are displayed in Table 1.

Based on the meanings and the relationships among these personality traits as well as descriptions of personality dimensions identified in the literature, the analysis reveals 9 factors or dimensions of country personality of Vietnam. Dimension 1 represents the country personality of competence dimension ( 7 items: hard-working, secure, intelligent, technical, corporate, successful, and leader). Dimension 2 represents the excitement dimension (7 items: exciting, darling, sentimental, friendly, trendy, honest, and sincere). Dimension 3 reflects the ruggedness dimension ( 5 items: outdoorsy, masculine, western, tough, and rugged). Dimension 4 reveals the sophistication dimension (4 items: upper-class, glamorous, good-looking, and smooth). Dimension 5 represents the new generation dimension ( 3 items: young, imaginative, and up-to-date). Dimension 6 reflects the down-to-earth dimension (3 items: down-to-earth, family-oriented, and small-town). Dimension 7 indicates the elegance dimension ( 3 items: independent, charming, and feminine). Dimension 8 represents the originality dimension ( 2 items: real and original). Finally, dimension 9 exhibits the spiritedness dimension ( 2 items: spirited and cool).

Table 1: Factor analysis personality of country

\begin{tabular}{|l|l|l|l|l|l|l|l|l|l|l|l|l|}
\hline \multicolumn{2}{|l|}{ Dimensions } & & & & & & & \\
\hline \\
\hline
\end{tabular}




\begin{tabular}{|l|l|l|l|l|l|l|l|l|l|l|l|l|}
\hline 16. & masculine & & & .701 & & & & & & & 3.40 & .93 \\
\hline 17. & western & & & .817 & & & & & & & 3.33 & .95 \\
\hline 18. & tough & & & .786 & & & & & & & 3.45 & .93 \\
\hline 19. & rugged & & & .795 & & & & & & & 3.24 & .99 \\
\hline 20. & upper class & & & & .699 & & & & & & 3.07 & .77 \\
\hline 21. & glamorous & & & & .781 & & & & & & 2.82 & .82 \\
\hline 22. & good looking & & & & .654 & & & & & & 3.13 & .85 \\
\hline 23. & smooth & & & & .722 & & & & & & 3.13 & .88 \\
\hline 24. & young & & & & & .740 & & & & & 3.22 & .91 \\
\hline 25. & imaginative & & & & & .690 & & & & & 3.24 & .87 \\
\hline 26. & up-to-date & & & & & .716 & & & & & 3.09 & .89 \\
\hline 27 & down-to-earth & & & & & & .662 & & & & 3.45 & .86 \\
\hline 28 & family-oriented & & & & & & .738 & & & & 3.47 & .86 \\
\hline 29. & small-town & & & & & & .693 & & & & 3.35 & .84 \\
\hline 30. & independent & & & & & & & .633 & & & 3.71 & .85 \\
\hline 31. & charming & & & & & & & .581 & & & 3.53 & .94 \\
\hline 32. & feminine & & & & & & & .566 & & & 3.64 & .94 \\
\hline 33. & Real & & & & & & & & .598 & & 3.50 & .91 \\
\hline 34. & original & & & & & & & & .657 & & 3.60 & .95 \\
\hline 35. & Spirited & & & & & & & & & .782 & 3.63 & .91 \\
\hline 36. & Cool & & & & & & & & & .570 & 3.39 & .94 \\
\hline Eigenvalues & 4.43 & 4.12 & 3.47 & 3.06 & 2.77 & 2.24 & 2.13 & 1.98 & 1.58 & & \\
\hline Variance explained (\%) & 10.5 & 9.81 & 8.26 & 7.29 & 6.59 & 5.34 & 5.06 & 4.72 & 3.77 & & \\
\hline
\end{tabular}

\section{Discussions}

\section{Summary}

Results from a factor analysis reveal 9 dimensions of Vietnam's country personality. These dimensions include competence, excitement, ruggedness, sophistication, new generation, down-to-earth, elegance, originality, and spiritedness.

\section{Theoretical Implications}

Based on the study results, the current research provides a number of contributions to the areas of country personality, country branding, and brand personality. From the theoretical perspective, as there have been relatively few studies specifically designed to investigate country personality, our research is therefore considered a step further to fill in this void. In addition, the results from our study reveal some dimensions similar to those identified in other research. For example, the competence, excitement, ruggedness, and sophisticiation dimensions uncovered in the present study are quite similar to those identified in research conducted with traditional branded products (e.g., Aaker 1997), therefore confirming the similarity between brand personality and country personality in this respect. However, there are also some new dimensions uncovered in the present study. These include new generation, down-to-earth, elegance, originality, and spiritedness. In this light, this discrepancy may highlight the unique aspect of country personality which is different from those of traditional 
branded personality while the similar dimensions reflect the universality or the commonness between product personality and country personality. Further research may consider examining this issue in greater depth.

Furthermore, from a methodological perspective, these new personality dimensions obtained from this survey are those which have not been previously identified in the literature. As a consequence, the implications in this regard are twofold. First, this may also reflect country personality dimensions unique to Vietnam. Next, this may suggest an opportunity for future research. That is, further investigation of these new country personality dimensions would provide an interesting avenue to better understand the country personality construct.

\section{Managerial Implications}

In addition to the academic contributions, the results from the present study also provide several practical guidelines in building Vietnam's country personality. First, the competence dimension may reflect that Vietnam is a country with highly competent or highly skilled people. Therefore, the Vietnamese government may use this dimension to attract foreign investment. Next, the excitement and ruggedness dimensions may be communicated through tourism attractions with such characteristics. These may include, for example, the sand dunes of Mui Ne, Cu Chi tunnels, Ha Long bay, and Phong NhaKe Bang national park as they could be particularly interesting for adventurous tourists. However, for those who love sophistication and elegance, Vietnam may focus on such tourism attractions as well-maintained and glamorous colonialstyle building as well as Hue Citadel and Imperial Citadel of Thang Long. In addition, various forms of high culture and art can be used to convey this personality. In terms of the new generation dimension, Vietnam may possess this characteristic due to the fact that much of its population is still young, teenagers or in the working age group while many other countries are approaching toward the population aging. This group of people is therefore more likely to be up-to-date and imaginative. Vietnam thus may manage this personality by training these people to have marketable skill and abilities in order to attract more foreign investment. Next, the down-to-earth dimension may reflect the relatively low labor cost which could also be useful in attracting foreign investors. Furthermore, the originality dimension may reflect the traditional lifestyle of Vietnamese people where bicycles and traditional forms of architecture and costume may constitute some examples. Finally, based on the spirited dimension, Vietnam must work hard and have a strong determination concerning their longterm national agenda.

\section{Study Limitations and Avenues for Future Research}

Certain limitations in this study may suggest fruitful avenues for future research. First, future studies may examine the personality of other countries such as Cambodia, Laos, and Timor Leste as there are relatively little research concerning them. In this light, research with other underrepresented Asian countries will respond to the comparative shortage of research in this issue among this region. Furthermore, the results of the present study come from student sample. They may not therefore be a true representative of the whole population. As a consequence, future research may consider differnt groups of samples to provide the generalizability of the research results. Finally, in addition to a survey method as employed in this study, depth interview (cf., Blythe 2007), experiment (cf.,Johar, Sengupta and Aaker 2005) and content analysis (cf., Opoku, Abratt and Pitt 2006) will also provide additional insights in country personality.

\section{References}

[1] Aaker, J. L. (1997). Dimensions of brand personality, Journal of Marketing Research, 34, 356-347.

[2] Amatyakul, S. \& Polyorat, K. (2016). City brand personality: The application of brand personality concept in the city context, Review of Integrative Business \& Economics, 5(4), 108-121.

[3] Ang, S.H. \& Lim, E.A.C. (2006). The influence of metaphors and product type on brand personality perceptions and attitudes, Journal of Advertising, 35(2), 39-53.

[4] Anholt, S. (2003). Brand New Justice: The Upside of Global branding, UK: Butterworth Heinemann.

[5] Azoulay, A. \& Kapferer, J.N. (2003). Do brand personality scales really measure brand personality?, Brand Management, 11(2), 143-155.

[6] Balaji, M. S. \& Raghavan, S. ( 2011). Communicating brand personality - The moderating role of human personality, Great Lakes Herald, 5, 24-36.

[7] Balakrishnan, B. KPD., Lee, S., Shuaib, A.S.Md. \& Marmaya, N.H. (2009). The impact of brand personality on brand preference and loyalty: Empirical evidence from Malaysia, Business Education \& Accreditation, 1(1), 109-119. 
[8] Blythe, Jim (2007), Advertising creatives and brand personality: A grounded theory perspective, Brand Management, 14 (4), 284-294.

[9] Brislin, R. W. (1980). Translation and content analysis of oral and written material. in Handbook of Crosscultural Psychology, United States: Ally \& Bacon, 12, 389-444.

[10] Dezan Shira \& Associates (2017, January 23). Vietnam in 2017: Spotting opportunities for foreign direct investment. Retrieved from https://www.cfoinnovation.com/story/12529/vietnam-2017-spotting-opportunitiesforeign-direct- investment

[11] Ekhlassi, A., Nezhad, M. H., Far, S. A. \& Rahmani, K. (2012). The relationship between brand personality and customer personality, gender and income: A case study of the cell phone market in Iran, Journal of Targeting, Measurement \& Analysis for Marketing, 20, 158-171.

[12] Fan, Y. (2009). Branding the nation: Towards a better understanding, Brunel Business School Research Papers.

[13] Farhat, R. \& Khan, B. M. (2011). Importance of brand personality to customer loyalty: A conceptual study," New Media and Mass Communication, 1, 4-10.

[14] Goldsmith, R. \& Goldsmit, E. (2012). Brand personality and brand engagement, North American Business Press, 12, 11-20.

[15] Johar, Gita Venkataramani, Jaideep Sengupta and Jennifer L. Aaker (2005), Two roads to updating personality impressions: Trait versus evaluative inferencing, Journal of Marketing Research, (November), 458469.

[16] Kaneva, N. (2011). Nation branding: Toward an agenda for critical research, International Journal of Communication, 5,117-141.

[17] Kim, H. R., Lee, M. \& Ulgado, F. M. (2005). Brand personality, Self-congruity and the consumer-brand relationship, Asia Pacific Advances in Consumer Research, 111-117.

[18] Lee, J. W. (2009). Relationship between consumer personality and brand personality as self-concept: from the case of Korean brands, Academy of Marketing Studies Journal," 13, 25-44.

[19] Lin, L.Y. (2010). "The relationship of consumer personality trait, brand personality and brand loyalty: an empirical study of toys and video games buyersnull, Journal of Product \& Brand Management, 19, 4-17.

[20] Mugobo, V.V. \& Ukpere, W.I. (2011). Is country branding a panacea or poison?, African Journal of Business Management, 5(20), 8248-8255.

[21] Opoku, R., Abratt, R. \& Pitt, L. (2006), Communicating brand personality: Are the website doing the talking for the top South African business schools?," Brand Management, 14 (1/2), 20-39.

[22] Parker, B.T. (2009. A comparison of brand personality and brand user-imagery congruence, Journal of Consumer Marketing, 26, 175-184.

[23] Pitt, L. F., Opoku, M. Hultman, R. A., \& Spyropoulou, S. (2007). What I say about myself: Communication of brand personality by African countries, Tourism Management, 28, 835-844.

[24] Plummer, J. T. (2000). How personality makes a difference," Journal of Advertising Research, 40, 79-83.

[25] Ramaseshan, B. \& Tsao, H.Y. (2007). Moderating effects of the brand concept on the relationship between brand personality and perceived quality, Journal of Brand Management, 14, 458.

[26] Sirisoontorn, S., \& Polyorat, K. (2013). Impact of country personality and country image on country of origin and purchase intentions for global supply chain management, in Proceeding of the 2nd International Conference on Product and Supply Chain Management (ICPSCM), 2013. pp. 347-354.

[27] Sung, Y., \& Tinkham, S. F. (2005). Brand personality structures in the United States andKorea: Common and culture-specific factors, Journal of Consumer Psychology, 15, 334-350.

[28] TalkVietnam. (2017). Export enjoys strong growth:2016. Retrieved from https://www.talkvietnam.com/2017/03/export-enjoys-strong-growth-2016-report,

[29] Vietnam tourist arrivals (https://tradingeconomics.com/vietnam/tourist-arrivals) 